\title{
No short-term impact of honey bees on the reproductive success of an Australian native bee ${ }^{1}$
}

\author{
Dean R. PAINI ${ }^{\mathrm{a} *}$, Matthew R. WILLIAMS ${ }^{\mathrm{b}}$, J. Dale RoBeRTS ${ }^{\mathrm{a}}$ \\ a School of Animal Biology M092, University of Western Australia, 35 Stirling Hwy, Crawley, WA 6009, \\ Australia \\ b CALM Science Division, Department of Conservation and Land Management, Locked Bag 104, \\ Bentley Delivery Centre, WA 6983, Australia
}

Received 13 December 2004 - revised 12 April 2005 - accepted 4 May 2005

Published online 15 November 2005

\begin{abstract}
The European honey bee was introduced to Australia 180 years ago and feral populations now occupy most coastal environments. Although much debate has taken place regarding the possible impact of honey bees on Australian native bees, there has been little direct research. This study presents the results of a replicated Before-After Control-Impact (BACI) experiment simulating the putative impact of feral honey bees on an undescribed species of Australian solitary bee (Megachile sp. M323/F367). Although a large resource overlap occurred between the two species, there was no significant change in the reproductive success of the native bee. The realised precision of the experiment was assessed and showed appropriate sensitivity for three important reproductive variables. The native bee, being better adapted to the high summer temperatures experienced during the period of this experiment, may be able to withstand honey bee competition.
\end{abstract}

BACI / competition / Apis mellifera / Megachile / resource overlap / introduced species

\section{INTRODUCTION}

For thousands of years humans have been translocating animals, either deliberately or accidentally, to countries and ecosystems outside their natural range. Freed from the predatory, parasitic and competitive restraints experienced in their native environments, many of these animals have had severe impacts on indigenous fauna and flora. One way invading animals can impact the natural ecosystem is through competition and there are many examples from around the world of the negative, competitive impact of introduced mammals (Manchester and Bullock, 2000), birds (Miller, 1967), fish (Greger and Deacon, 1988;
Zale and Gregory, 1990) and invertebrates (Juliano, 1998; Byers, 2000; Manchester and Bullock, 2000; Kiesecker et al., 2001; Schellhorn et al., 2002).

Honey bees (Apidae: Apinae) were successfully imported to Australia for honey production in 1822 and escaped into the natural environment soon afterwards, becoming feral (Paton, 1996). Today they occur in all states and territories (Paton, 1996) and may be able to maintain viable populations without immigration from commercial hives (Oldroyd et al., 1997). In the last 30 years, there has been a great deal of debate over the impact of honey bees on native fauna (Paton, 1996). Of all fauna, other bees are the most likely candidates for

* Corresponding author: drpaini@ifas.ufl.edu

${ }^{1}$ Manuscript editor: Marla Spivak 
competition as many are of a similar size and require the same resources (pollen and nectar) for their progeny.

Subsequently, researchers have investigated honey bee impact on native bees but a recent review of these studies found that most had focused on resource overlap or visitation rates (Paini, 2004a). While these studies indicate the potential for competition between native and honey bees, they do not measure any impacts on abundance or reproductive success of native bees in response to honey bees and subsequently are limited in the conclusions that may be drawn.

Worldwide, few studies have attempted to measure native bee reproductive success in response to honey bees and the results so far have been equivocal (see Paini, 2004a for review). In Australia, only one study has investigated the impact of honey bees on native solitary bees (Paini, 2005). As the majority of Australia's bees are solitary, such an investigation on this richly diverse group would seem paramount. Equally, there has only been one investigation into the impact of feral honey bees on native bees in Australia (Schwarz et al., 1991, 1992a, b). Feral honey bees do not occur in the densities found at apiary sites, where beekeepers can place up to 100 hives for 13 months. However, feral honey bees remain at the same location throughout the year and may have a significant impact on native bees when floral resources are limiting.

This paper reports the results of a replicated BACI (Before-After Control-Impact) experiment (Stewart-Oaten et al., 1986) into the impact of feral honey bees on the reproductive success of a native solitary bee, an undescribed species in the genus Megachile.

\section{METHODS}

\subsection{Bee biology}

The native bee species studied is an undescribed species referred to by its WA Museums register/ accession number: M323/F367 (herein referred to as Megachile sp. 323) (Megachilidae: Megachilinae). Little is known of Megachile sp. 323 biology. Only one paper has been previously published based on trap nest data (Paini, 2004b). Females nest during the spring and summer months from October to April with the peak in nest production in February. As the nesting season progresses larvae enter diapause at increasing rates and do not emerge until the following season. Within a nest, males always occupy the outermost cells and consequently emerge first (protandry). In addition, males are smaller than females and there is a female sex biased ratio in offspring. The reasons for this bias are unclear but may be caused by local resource enhancement as a result of nest clustering (Paini, 2004b).

\subsection{Study sites}

The experiment was conducted in the Northern Beekeepers Nature Reserve ( $\left.30^{\circ} 00^{\prime} \mathrm{S}, 115^{\circ} 05^{\prime} \mathrm{E}\right)$, approximately $250 \mathrm{~km}$ north of Perth, Western Australia, from October 2000 to March 2001. As explained above, female Megachile sp. 323 nest during this period when floral resources are minimal. Professional beekeepers only place their hives in this area over the winter period (June-August) and any competition experienced by Megachile sp. 323 will be from feral honey bees.

Eleven study sites with similar vegetation profiles and separated by a minimum of $1.5 \mathrm{~km}$ were selected. All sites were located within a $55 \mathrm{~km}^{2}$ area. The study sites were randomly allocated to one of either six control or five treatment sites. Within each study site, two parallel transects $100 \mathrm{~m}$ long and $25 \mathrm{~m}$ apart were established.

Hive honey bees at low density were used to simulate the impact of feral honey bees and the BACI design assessed the impact of these honey bees by comparing any differences between control and treatment sites before the impact was introduced with any differences after the impact (Stewart-Oaten et al., 1986). Both control and treatment sites were assessed every 4 weeks (repeated measure) throughout the experiment. Assessment occurred on three occasions before honey bees were introduced from 15 November 2000. On 15 January 2001, two honey bee hives were introduced to each treatment site to simulate feral honey bees. Sites were then assessed three more times until 25 March 2001 and the experiment was terminated by removing honey bee hives.

\subsection{Honey bee densities}

Honey bee densities were assessed before hives were introduced to ensure there were minimal levels of truly feral honey bees present and to measure any existing differences between treatment and control sites. Honey bee densities were monitored after the introduction of hives to ensure treatment sites had higher levels of honey bees than control sites. A census of honey bees was made every $10 \mathrm{~m}$ along both trap nest transects by scanning the surrounding area for $30 \mathrm{~s}$ and counting all bees sited. Values for each 
census point were totalled to give the number of honey bees seen at each site.

The artificial inflation of honey bee densities in this experiment may not be regarded as a test of feral honey bees as the density of honey bees was increased significantly above that of original feral levels (see results). However, feral honey bee hives do not occur in a uniform distribution in this reserve, being limited to limestone caves where as many as ten feral honey bee hives can be found in one cave (DRP personal observation). In the $55 \mathrm{~km}^{2}$ area in which this experiment was conducted, there were few caves and the number of feral honey bees was considerably lower than expected in other regions of this reserve where limestone caves are more numerous (DRP personal observation). The addition of two honey bee hives per site to simulate feral levels of honey bees was therefore justified.

\subsection{Resource overlap}

Resource overlap was assessed to determine if honey bees and Megachile sp. 323 were utilising the same floral resources. Pollen extracted from nests of Megachile sp. 323 was compared with both pollen and the pollen in honey collected by honey bees. One Megachile sp. 323 nest from each site and each repeated measure was vigorously flushed with $10 \mathrm{~mL}$ of water to extract pollen and larval faeces. The resulting fluid was then acetolysed following the standard technique of Erdtman $(1952,1960)$ (see also Phipps and Playford, 1984). The extracted pollen was preserved on microscope slides and later matched to a reference collection of pollen collected from plant species in the area. One reference slide contained pollen from two Melaleuca spp. (M. systema and M. leuropoma) (Myrtaceae) and it was not possible to distinguish between these two species.

Honey bees may collect nectar, which is converted to honey, from different plant species than they collect pollen from. Therefore, both honey and pollen were collected from honey bee hives at each treatment site for analysis. Honey bee pollen was collected over a two-day period using pollen traps (Smith and Adie, 1963). A sub-sample $(0.5 \mathrm{~mL}$ volume) of each pollen sample was mixed with $9.5 \mathrm{~mL}$ of water and acetolysed before being preserved on microscope slides. To determine the source of the honey, one hive frame was removed from a hive at each site and replaced with a fresh frame so any honey present would have only been collected in the period since the previous repeated measure. Each frame was scraped for honey, filtered through a container lid punched with holes of approximately $1 \mathrm{~mm}$ diameter to remove wax and then diluted by $50 \%$ with warm water. This honey/water mixture was centrifuged at $3500 \mathrm{rpm}$ for 3 minutes and the supernatant poured off. The remaining pellet was diluted by $50 \%$ with ethanol, heated in a water bath for 5 minutes to fully dissolve the honey before being centrifuged at $3500 \mathrm{rpm}$ for 3 minutes. The supernatant was poured off and the remaining pellet was resuspended in $9.5 \mathrm{~mL}$ of water and centrifuged at $3500 \mathrm{rpm}$ for 3 minutes. This last step was repeated two more times before the pollen was acetolysed and preserved on microscope slides.

Each slide was scanned from left to right until 100 pollen grains were counted and the relative frequency of each species of pollen was then calculated. Resource overlap between Megachile sp. 323 and honey bees was then calculated according to Colwell and Futuyma (1971):

$$
\mathrm{RO}_{i h}=1-1 / 2 \sum_{k}\left|p_{i k}-p_{h k}\right|
$$

where $p_{i k}$ is the average proportion of pollen type $k$ of species $i$ and $p_{h k}$ is the average proportion of pollen type $k$ in species $h$. Values of RO range from 0 to 1.0 with 0 indicating no overlap and 1.0 indicating complete overlap. The difficulty in identifying pollen to species level meant that only pollen species identified from Megachile sp. 323 nests were identified in honey bee samples. Any other pollen species were classified as 'other species' as this did not affect resource overlap calculations.

\subsection{Reproductive success}

Female Megachile sp. 323 will nest in 'trap nests', drilled sections of untreated pine batons $(2 \mathrm{~cm} \times 2 \mathrm{~cm} \times 7 \mathrm{~cm})$. Females build cells in these holes and provision them with nectar and pollen for their progeny, which provides an opportunity to monitor reproductive success in the presence and absence of honey bees.

The preferred hole-diameter of trap nests for this Megachile sp. is $7.0 \mathrm{~mm}$ (Paini, 2004b). Four drilled batons, each containing a single $7.0 \mathrm{~mm}$ diameter hole, were tied together using wire to make a bundle. A bundle of trap nests was placed at $10 \mathrm{~m}$ intervals along the two parallel transects, giving 80 trap nests per site. Bundles were hung from shrubs at a height of $10-150 \mathrm{~cm}$. All 11 sites were visited every 4 weeks when all trap nests were removed and replaced with fresh ones. Any trap nests that were partially completed were left until the following visit. Females of Megachile sp. 323 cap nests with sand grains and small twigs so completed nests were easily recognised (Paini, 2004b).

The completed nests were returned to the laboratory and held in a constant temperature (CT) room maintained at a light and temperature regime that matched the average environmental conditions for that region, adjusted monthly. After 3-4 weeks all adults that emerged from nests were weighed and then killed by freezing. Progeny from nests collected 
at the end of the season delayed development (diapause) and did not emerge until the beginning of the following season. These nests were stored outside between seasons and returned to the CT room just prior to emergence.

Data collected from trap nests were number of progeny, progeny mass, sex, percentage of nests with failed eggs/pupae, percentage of nests in diapause and number of parasitoids. As nest construction was not monitored, it was not possible to determine if the same female laid all eggs in the one nest. In analysing progeny mass, individuals were therefore used as independent data. However, the number of eggs per nest was analysed to give an indication of the population's egg production and the number of nests per site was also analysed to indicate the overall nest production.

\subsection{Statistical analysis}

A nested repeated measures analysis of variance was used to compare honey bee densities and the reproductive success of Megachile sp. 323 between treatment and control sites before and after honey bees were introduced. The initial design comprised three repeated measures before and three after the impact. Subsequent analysis revealed there was no resource overlap between honey bees and native bees during the second and third repeated measures after the introduction of honey bees (see results). For the analysis of reproductive success, the design was then modified to comprise three periods: before impact; after impact (a - resource overlap); and after impact ( $b$ - no resource overlap). Data analysis was carried out using SAS version 6 (SAS Institute, 1989). This analysis is a slight modification of the traditional BACI design but still focuses on the after impact (a) period while accounting for natural differences between sites during the other periods. The important interaction was that of period $\mathrm{x}$ treatment effect which indicated if there were any differences between control and treatment sites in each of the three periods and therefore if honey bees had an impact on Megachile sp. 323.

The realised precision of the experiment was assessed for any reproductive success variables that did not show a significant impact effect by calculating the percentage of change detectable with $95 \%$ confidence. This value gives an indication of the sensitivity of the experiment.

$$
\% \text { detectable change }(\% \mathrm{DC})=\left(\frac{\mathrm{Q} \times \mathrm{se}}{\mathrm{u}}\right) \times 100
$$

where $\mathrm{Q}$ is the studentized range statistic, se is the standard error and $\mathrm{u}$ is the overall mean. These values were compared to the actual \% change (\%AC).

$$
\% \mathrm{AC}=\frac{\mathrm{c}-(\mathrm{e}-\mathrm{f})}{\mathrm{u}} \times 100
$$

Table I. Mean number of honey bees observed at control and treatment sites $( \pm \mathrm{SE})$, before and after honey bees were introduced to treatment sites. Honey bee numbers at treatment sites increased substantially after placement of honey bee hives $\left(F_{1,36}=51.42, P=0.0001\right)$.

\begin{tabular}{lcc}
\hline & Before & After \\
\hline Control & $0.58( \pm 0.50)$ & $0.38( \pm 0.19)$ \\
Treatment & $0.50( \pm 0.34)$ & $8.35( \pm 1.16)$ \\
\hline
\end{tabular}

where $\mathrm{c}$ is the mean difference between the means of treatment and control sites from both before impact and after impact (period b). This gives an estimate of the mean change expected without any influence of honey bees. The value of $(e-f)$ is the difference between the means of treatment and control sites after impact (period a).

\section{RESULTS}

\subsection{Honey bee density}

Before honey bees were introduced, there were very few honey bees present at either control or treatment sites further justifying the introduction of bees to simulate a feral load. Honey bee densities were significantly higher in treatment sites than control sites after hives were placed at treatment sites (Tab. I).

\subsection{Resource overlap}

During the period before the introduction of honey bees, $80 \%$ of pollen collected from nests of Megachile sp. 323 was from Jacksonia calcicola. The other $20 \%$ was Melaleuca systema and/or M. leuropoma (see methods). Jacksonia calcicola was the only pollen found in nests of Megachile sp. 323 from both control and treatment sites after the introduction of honey bees. Jacksonia calcicola pollen was also found in honey bee honey during the first assessment period after their introduction and the niche overlap was estimated to be 0.74 . In subsequent assessments, no honey was produced by any of the hives. Jacksonia calcicola pollen was not found in honey bee pollen at any assessment time. 


\subsection{Reproductive success}

Megachile sp. 323 constructed a total of 270 nests at the 5 treatment sites and 329 nests at the 6 control sites. The number of completed nests at both control and treatment sites increased from before impact to after impact (a) before decreasing (Fig. 1a) $\left(F_{2,27}=26.2, P<\right.$ $0.05)$. At control sites, 184 males and 753 females emerged from nests and at treatment sites, 117 males and 680 females emerged.

Throughout the experiment, sex ratio $(17 \%$ males $\pm 2.0 \mathrm{SE}$ ), and percentage of nests with dead progeny $(14.2 \% \pm 2.8 \mathrm{SE})$ all remained unchanged $\left(F_{2,15}=0.8\right.$, n.s., $F_{2,15}=0.6$, n.s. respectively). However, both male mass (Fig. 1c) and the number of progeny per nest (Fig. 1d) increased initially then decreased $\left(F_{2,8}=4.1, P<0.05, F_{2,14}=9.0, P<0.05\right.$ respectively). Female mass remained unchanged until the final period (after impact b) when it decreased $\left(F_{2,15}=6.4, P<0.05\right.$, Fig. 1b). The percentage of nests in diapause increased throughout the experiment $\left(F_{2,15}=\right.$ 54.5, $P<0.05$, Fig. 1e).

None of the parameters measured for $\mathrm{Meg}$ achile sp. 323 demonstrated a significant impact of honey bees (Tab. II). The percentage detectable change for male and female mass and for the number of progeny per nest was $30 \%$ or less (Tab. II). However, for the remaining variables, the experiment was only able to detect medium to large differences between control and treatment sites (70-316\%).

Seven nests were parasitized by a Leucospis sp. (Hymenoptera; Leucospidae) and one nest was parasitized by a Gasteruption sp. (Hymenoptera; Gasteruptiidae). All these nests were parasitized before honey bees were introduced so no analysis was performed.

\section{DISCUSSION}

The lack of honey production by honey bees in the last eight weeks of this experiment was probably caused by the high daytime temperatures experienced during this period (observed mean maximum for Jan.-Feb., 2001 was $29.9{ }^{\circ} \mathrm{C}$, maximum recorded $41.2^{\circ} \mathrm{C}$, overall mean maximum for Jan.-Feb. was $30.3{ }^{\circ} \mathrm{C}$, overall maximum recorded $45.2^{\circ} \mathrm{C}$; data provided by the Western Australian Bureau of
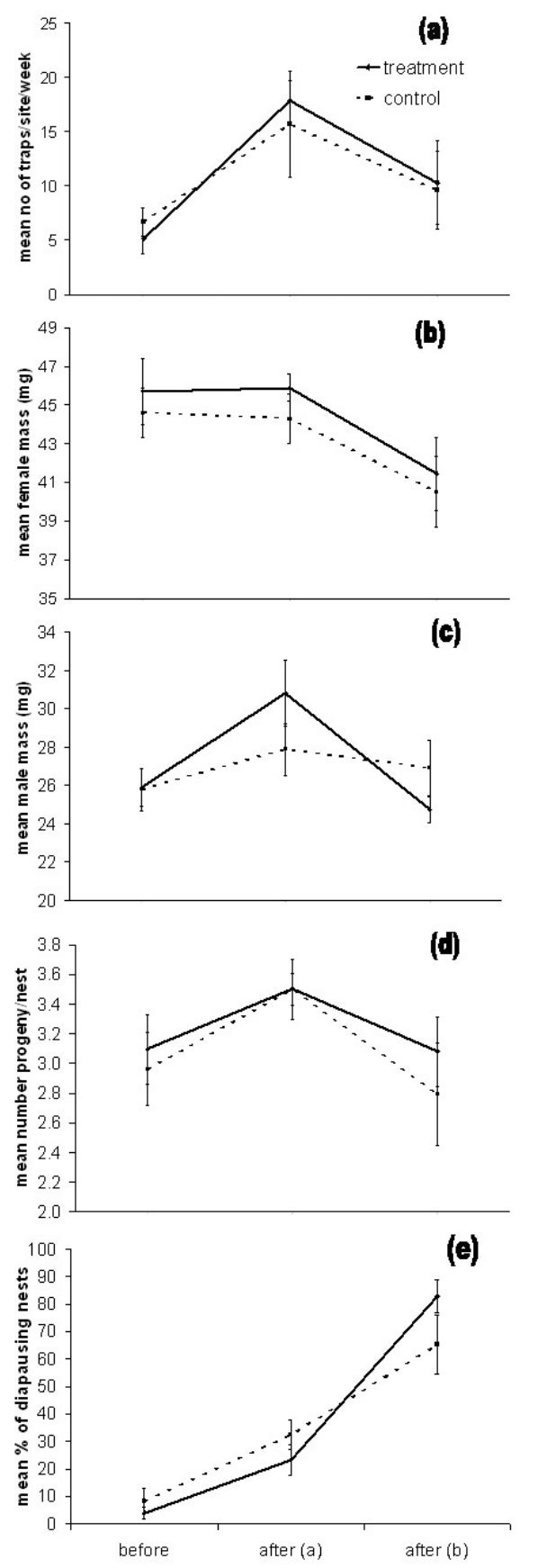

Figure 1. Parameters of Megachile sp. 323 measured at control and treatment sites. (a) Seasonal variation in mean nesting, (b) mean female mass, (c) mean male mass, (d) mean number of progeny per nest, (e) and mean percentage of nests in diapause. Error bars are $\pm \mathrm{SE}$. 
Table II. Results of nested repeated measures analysis of variance (period $\times$ treatment) plus the estimated percentage actual change (\% AC) and percentage detectable change $(\% \mathrm{DC})$ for all reproductive success parameters of Megachile sp. 323. Negative values indicate that the mean for treatment sites was smaller than control sites.

\begin{tabular}{lccccc}
\hline Parameter & $F$ & df & $P$ & \%AC & $\%$ DC \\
\hline Female mass & 0.13 & 2,15 & 0.88 & 1.3 & 15.0 \\
Progeny/nest & 0.06 & 2,14 & 0.94 & -7.8 & 26.6 \\
Male mass & 1.52 & 2,8 & 0.28 & 12.2 & 30.1 \\
No of nests & 0.39 & 2,27 & 0.68 & 30.6 & 70.0 \\
Diapausing nests & 2.62 & 2,15 & 0.10 & 39.9 & 103.6 \\
Sex ratio & 0.41 & 2,15 & 0.67 & -37.7 & 164.2 \\
Dead progeny & 0.17 & 2,15 & 0.84 & 31.2 & 316.2 \\
\hline
\end{tabular}

Meteorology). At high air temperatures, honey bees use water to cool the hive and workers normally devoted to foraging for nectar are redirected to searching for and collecting water (Heinrich, 1993). During this experiment, honey bees were seen aggregating around nearby water sources and very few were observed collecting nectar (DRP, pers. obs.). This commitment to reducing hive temperature would have reduced foraging times and limited honey production. As honey bee foraging was curtailed during this period, there was no resource overlap during the last eight weeks of the experiment. Hence, only a four-week period of resource competition was actually measured.

To measure resource overlap we counted the relative densities of pollen grains (Colwell and Futuyma, 1971). A more thorough analysis, accounting for pollen volume to generate a Morista-Horn similarity index (Villanueva-G and Roubik, 2004), may have been a more accurate measure of resource overlap. Resource overlap only determines the potential for competition and does not measure competition directly. Consequently we used a simpler measure of resource overlap and focussed on the reproductive success of Megachile sp. 323 to evaluate competition.

$J$. calcicola pollen was only found in the honey of honey bees as they were collecting nectar from this plant, while Megachile sp. 323 was collecting pollen. The implication is that these two bee species were collecting different resources and this might explain the lack of competition. While Megachile sp. 323 females were clearly collecting pollen from Jacksonia it is likely they were also collecting nectar from Jacksonia as solitary bees such as Megachilidae commonly collect nectar and pollen from the same plant species (Thomson, 1988; Neff and Danforth, 1991; Scott et al., 1993; Cane, 1996; Goodell, 2003; Williams and Tepedino, 2003). When honey bees were collecting nectar in this experiment, the resource overlap with Megachile sp. 323 was 0.74. Previous studies assessing resource overlap between honey bees and native bees have mostly reported values below 0.5 (Roubik, 1996; Wilms et al., 1996; Steffan-Dewenter and Tscharntke, 2000) although Wilms and Wiechers (1997) found values between honey bees and two Melipona spp. that varied seasonally between 0 and 0.76 . In Australia, Paini (2005) found resource overlap between honey bees and Hylaeus alcyoneus (Colletidae: Hylaeinae) varied from 0.52 to 0.97. Therefore, the level of resource overlap between honey bees and Megachile sp. 323 in this experiment was high for a short period.

This study found that over a short time period, feral honey bees do not negatively impact on the native solitary bee Megachile sp. 323. This lack of competition may have been due to a lack of resource overlap between honey bees and Megachile sp. 323, or if there was resource overlap, the resource may not be limiting. In addition, Megachile sp. 323 may be better adapted to the prevailing summer temperature regimes experienced in this region and thus able to withstand competition from feral honey bees. However, most feral honey bee colonies in this area are located inside limestone 
caves (DRP, pers. obs.). Feral colonies occupying caves experience cooler environmental conditions and the workers would spend less time foraging for water to maintain hive temperature than the hives used in this experiment.

In concluding that there was no apparent detectable impact of honey bees the sensitivity of this experiment should also be considered. This experiment was sensitive enough to detect relatively small (15-30\%) changes in three parameters (male and female progeny mass, and number of progeny per nest), which compares favourably with other impact studies (Calver et al., 1999; Strehlow et al., 2002). In attempting to determine the impact of feral honey bees on native bees, these three variables plus the number of nests produced are of most relevance. Male and female progeny mass is directly correlated with provision mass (Frohlich and Tepedino, 1986; Johnson, 1988) and if Megachile sp 323 had experienced competition from feral honey bees, provision mass may have been reduced, resulting in a decrease in progeny mass. Alternately, reduced resources may have caused females to produce fewer eggs or to compensate for the reduced resources by foraging longer thereby producing fewer nests in total. Clearly, this design provides adequate sensitivity for the first three variables. Although not as sensitive for detecting a change in nest numbers, it could detect a large $(70 \%)$ decrease in nest numbers which would result from a high level of competition from honey bees. This design could be improved by increasing the number of sites or more appropriately, extending the experiment over more than one season or extending the overlap period.

The short term nature of this experiment which resulted in a four week period in which honey bees and Megachile sp. 323 were in competition may not truly reflect the result of the long term presence of honey bees. Although this experiment could detect as little as a $15 \%$ difference between treatment and control, the actual impact of honey bees may be smaller than our detectable limit. If that small effect was aggregated over a long period the impact might still be significant. Future studies should consider methods that will extend the period of time in which this impact occurs. In this way we could predict more accurately the long term impact of honey bees on this native bee species.
Presently, only nine studies worldwide have investigated native bee reproductive success in response to honey bees (see Paini, 2004a for review plus Thomson, 2004; Paini, 2005). In Australia, only one study has investigated the impact of feral honey bees (Schwarz et al., 1991, 1992a, b). Clearly, the impact of feral honey bees on native solitary bees in Australia remains unresolved and further research using a BACI design experiment with either the addition of hive honey bees or the removal of feral honey bees is necessary.

\section{ACKNOWLEDGMENTS}

The Western Australian Department of Conservation and Land Management gave permission to undertake this study in the Northern Beekeepers Nature Reserve and provided financial support. Thanks go to Win Bailey and Ian Abbott for comments on the manuscript, Terry Houston for bee identifications, John Jennings for wasp identifications, Lynne Milne for instruction in pollen preparation and identification, John Davies and Ron Pollard for use of their hives, and all volunteers that assisted with fieldwork.

Résumé - Pas d'impact à court terme de l'Abeille domestique sur la fécondité d'une abeille indigène d'Australie. Les abeilles domestiques ou mellifères (Apis mellifera L.) ont été importées avec succès en Australie en 1822 pour la production de miel et se sont échappées dans l'environnement naturel peu de temps après, devenant alors sauvages (Paton, 1996). Durant les 30 dernières années, il y a eu un grand débat sur l'impact des abeilles mellifères sur la faune indigène (Paton, 1996). Cet article présente les résultats d'une expérimentation BACI (impact-avant-après-contrôle), avec répétition, sur l'impact des abeilles mellifères sauvages sur le succès reproductif d'une abeille solitaire indigène, une espèce non décrite de mégachile (Western Australian Museum $\mathrm{n}^{\circ}$ M323/F367, dénommée ici Megachile sp. 323). Des abeilles mellifères de ruches ont été utilisées pour simuler les abeilles mellifères sauvages et le dispositif BACI a évalué l'impact de ces abeilles en comparant les différences entre les sites témoins et les sites traités avant l'introduction avec les différences après l'introduction (Stewart-Oaten et al., 1986).

L'expérimentation a été conduite dans la Réserve Naturelle Apicole du Nord ( $\left.30^{\circ} 00^{\prime} \mathrm{S}, 115^{\circ} 05^{\prime} \mathrm{E}\right)$, située à environ $250 \mathrm{~km}$ au nord de Perth, Australie Occidentale, d'octobre 2000 à mars 2001. Megachile sp. 323 nidifie pendant cette période lorsque les ressources florales sont faibles. Onze sites d'étude (six témoins et cinq traités) possédant des profils de végétations semblables et distants d'au moins $1,5 \mathrm{~km}$ ont été retenus. 
Les abeilles mellifères n'ont eu aucun impact sur aucun des paramètres mesurant le succès reproductif de Megachile sp. 323. (Tab. II). La modification détectable pour la masse des mâles et des femelles et pour le nombre de descendants a été de $30 \%$ maximum (Tab. II). Pour les quatre variables néanmoins l'expérimentation n'a pu détecter que des modifications moyennes ou fortes entre les sites témoins et les traités (70-316\%). L'étude a montré que sur une courte période les abeilles mellifères sauvages n'ont pas d'impact négatif sur l'abeille solitaire indigène Megachile sp. 23, qui est peut-être mieux adaptée aux températures estivales de cette région et ainsi plus à même de résister à la compétition des abeilles mellifères sauvages.

\section{Megachile / Apis mellifera / compétition / espèce introduite}

Zusammenfassung - Honigbienen haben keinen kurzfristigen Einfluss auf den Fortpflanzungserfolg einer einheimischen australischen Biene. Honigbienen wurden in Australien im Jahr 1822 erfolgreich für die Honigproduktion importiert. Bereits nach kurzer Zeit entkamen einige Kolonien in die Naturlandschaft und verwilderten. Aufgrund dieser Tatsache stand in den letzten 30 Jahren verschiedentlich der möglich Impakt von Honigbienen auf die einheimische Bienenfauna zur Debatte (Paton, 1996).

In dieser Arbeit präsentieren wir die Ergebnisse einer wiederholten Vorher-Nachher KontrollImpaktstudie (BACI, Before-After Control-Impact, Stewart-Oaten et al., 1986) zum Einfluss wilder Honigbienen auf den Fortpflanzungserfolg einer noch unbeschriebenen einheimischen solitären Biene, Megachile sp. (Western Australian Museum, Nummer M323/F367, hier weiter als Megachile sp. 323 bezeichnet). Zur Simulierung des Einflusses wilder Honigbienen wurden Völker in Beuten in einem BACI-Design ausgebracht. Dies erlaubte den Vergleich von Kontroll- und Experimentlokalitäten vor und nach dem Ausbringen von Bienenvölkern. Der Versuch wurde an Megachile sp. 323 Nestern im Northern Beekeepers Nature Reserve $\left(30^{\circ} 00^{\prime} \mathrm{S}\right.$, $115^{\circ} 05^{\prime} \mathrm{O}$ ), ungefähr $250 \mathrm{~km}$ nördlich von Perth in Westaustralien durchgeführt. In der Versuchsperiode zwischen Oktober 2000 und März 2001 waren die floralen Ressourcen sehr gering. Als Untersuchungsorte wurden elf Lokalitäten (sechs Kontrollund fünf Versuchsorte) mit ähnlichem Vegetationsprofil und einem Minimalabstand von $1,5 \mathrm{~km}$ ausgewählt.

In keinem der untersuchten Parameter hatte die Präsenz von Honigbienen einen signifikanten Einfluss auf Megachile sp. 323 (Tab. II). Der Prozentsatz sichtbarer Unterschiede in der Männchen- und Weibchenmasse und in der Nachkommenzahl lag jeweils unter $30 \%$ (Tab. II). Für die restlichen Variablen zeigte der Versuch mittlere bis grosse Unterschiede zwischen den Kontroll- und Versuchsorten (70$316 \%)$.
Dieses Ergebnis zeigt, dass, über eine kurze Periode hinweg betrachtet, wilde Honigbienen keinen negativen Einfluss auf die einheimische solitäre Bienen Megachile sp. 323 haben sollten. Diese Biene scheint an das im Sommer herrschende Temperaturregime besser angepasst und dadurch in der Lage zu sein, der Konkurrenz von wilden Honigbienen zu widerstehen.

BACI / Konkurrenz / Apis mellifera / Megachile / Ressourcenüberlappung / eingeführte Arten

\section{REFERENCES}

Byers J.E. (2000) Competition between two estuarine snails: implications for invasions of exotic species, Ecology 81, 1225-1239.

Calver M.C., Bradley J.S., Wright I.W. (1999) Towards scientific contributions in applying the precautionary principle: an example from southwestern Australia, Pacific Conserv. Biol. 5 , 63-72.

Cane J.H. (1996) Nesting resins obtained from pollen host by an oligolectic bee, Trachusa larreae (Cockerell) (Hymenoptera: Megachilidae), J. Kans. Entomol. Soc. 69, 99-102.

Colwell R.K., Futuyma D.J. (1971) On the measurement of niche breadth and overlap, Ecology 52, 567-576.

Erdtman G. (1952) Pollen Morphology and Plant Taxonomy, Angiosperms, Almquist and Wiksell, Stockholm.

Erdtman H. (1960) The acetolysis method, A revised description, Svensk Botanisk Tidskrift 54, 561564.

Frohlich D.R., Tepedino V.J. (1986) Sex ratio, parental investment, and interparent variability in nesting success in a solitary bee, Evolution 40, 142-151.

Goodell K. (2003) Food availability affects Osmia pumila (Hymenoptera: Megachilidae) foraging, reproduction, and brood parasitism, Oecologia 137, 518-527.

Greger P.D., Deacon J.E. (1988) Food partitioning among fishes of the Virgin river, Copiea, 314 323.

Heinrich B. (1993) The Hot-Blooded Insects, Strategies and Mechanisms of Thermoregulation, Harvard University Press, Cambridge.

Johnson M.D. (1988) The relationship of provision weight to adult weight and sex ratio in the solitary bee, Ceratina calcarata, Ecol. Entomol. 13, 165170 .

Juliano S.A. (1998) Species introduction and replacement among mosquitoes: interspecific resource competition or apparent competition? Ecology 79, 255-268.

Kiesecker J.M., Blaustein A.R., Miller C.L. (2001) Potential mechanisms underlying the displacement 
of native red-legged frogs by introduced bullfrogs, Ecology 82, 1964-1970.

Manchester S.J., Bullock J.M. (2000) The impacts of non-native species on UK biodiversity and the effectiveness of control, J. Appl. Ecol. 37, 845864.

Miller R.S. (1967) Pattern and process in competition, Adv. Ecol. Res. 4, 1-74.

Neff J.L., Danforth B.N. (1991) The nesting and foraging behavior of Perdita texana (Cresson) (Hymenoptera: Megachilidae), J. Kans. Entomol. Soc. 64, 394-405.

Oldroyd B.P., Thexton E.G., Lawler S.H., Crozier R.H. (1997) Population demography of Australian feral bees (Apis mellifera), Oecologia 111, 381387.

Paini D.R. (2004a) Impact of the introduced honey bee (Apis mellifera) (Hymenoptera: Apidae) on native bees: A review, Aust. Ecol. 29, 399-407.

Paini D.R. (2004b) Nesting biology of an Australian resin bee (Megachile sp.; Hymenoptera: Megachilidae): a study using trap nests, Aust. J. Entomol. 43, 10-15.

Paini D.R. (2005) Commercial honey bees (Apis mellifera) reduce the fecundity of an Australian native bee (Hylaeus alcyoneus), Biol. Conserv. 123, 103-112.

Paton D.C. (1996) Overview of the feral and managed honeybees of Australia: distribution, abundance, extent of interactions with native biota, evidence of impacts and future research, Australian Nature Conservation Society.

Phipps D., Playford G. (1984) Laboratory techniques for extraction of palynomorphs from sediment. Papers, Department of Geology, University of Queensland 11, pp. 1-23.

Roubik D.W. (1996). African honey bees as exotic pollinators in French Guiana, in: Matheson A., Buchmann S.L., O'Toole C., Westrich P., Williams H. (Eds.), The conservation of bees, Academic Press, London, pp. 173-182.

SAS Institute (1989) SAS/Stat User's Guide, version 6, 4th ed. (2 Vols.), SAS Institute Inc., Carey.

Schellhorn N.A., Kuhman T.R., Olson A.C., Ives A.R. (2002) Competition between native and introduced parasitoids of aphids: nontarget effects and biological control, Ecology 83, 2745-2757.

Schwarz M.P., Kukuk P.F., Gross C.L. (1991) Assessment of competition between honeybees and native bees, July progress report, World Wildlife Fund Australia.

Schwarz M.P., Kukuk P.F., Gross C.L. (1992a) Assessment of competition between honeybees and native bees, January progress report, World Wildlife Fund Australia.
Schwarz M.P., Kukuk P.F., Gross C.L. (1992b) Assessment of competition between honeybees and native bees, July progress report, World Wildlife Fund Australia.

Scott P.E., Buchmann S.L., O'Rourke M.K. (1993) Evidence for mutualism between a flowerpiercing carpenter bee and ocotillo: use of pollen and nectar by nesting bees, Ecol. Entomol. 18, 234-240.

Smith M.V., Adie A. (1963) A new design in pollen traps, Can. Bee J. 74, 8.

Steffan-Dewenter I., Tscharntke T. (2000) Resource overlap and possible competiiton between honey bees and wild bees in central Europe, Oecologia 122, 288-296.

Stewart-Oaten A., Murdoch W.W.,Parker K.R. (1986) Environmental impact assessment: "pseudoreplication" in time? Ecology 67, 929-940.

Strehlow K., Bradley J.S., Davis J., Friend G.R. (2002) Short term impacts of logging on invertebrate communities in jarrah forests in south-west Western Australia, Forest Ecol. Manage. 162, 165-184.

Thomson J.D. (1988) Effects of variation in inflorescence size and floral rewards on the visitation rates of traplining pollinators of Aralia hispida, Evol. Ecol. 2, 65-76.

Thomson D. (2004) Competitive interactions between the invasive European honey bee and native bumble bees, Ecology 85, 458-470.

Villanueva-G R., Roubik D.W. (2004) Why are African honey bees and not European bees invasive? Pollen diet diversity in community experiments, Apidologie 35, 481-491.

Williams N.M., Tepedino V.J. (2003) Consistent mixing of near and distant resources in foraging bouts by the solitary mason bee Osmia lignaria, Behav. Ecol. 14, 141-149.

Wilms W., Wiechers B. (1997) Floral resource partitioning between native Melipona bees and the introduced Africanized honey bee in the Brazilian Atlantic rain forest, Apidologie 28, 339-355.

Wilms W., Imperatriz-Fonseca V.L., Engels W. (1996) Resource partitioning between highly eusocial bees and possible impact of the introduced Africanized honey bee on native stingless bees in the Brazilian Atlantic rainforest, Stud. Neotrop. Fauna Environ. 31, 137-151.

Zale A.Z., Gregory R.W. (1990) Food selection by early life stages of blue tilapia, Oreochromis aureus, in Lake George, Florida: overlap with sympatric shade larvae, Biol. Sci. 53, 123-129. 